\title{
UJI MUTU IKAN CAKALANG (Katsuwonus pelamis-L) DAN IKAN TONGKOL (Euthynnus affinis) SEGAR DI TPI TUMUMPA SELAMA PENYIMPANAN DINGIN
}

\author{
Desta Ekasari $^{1}$, I Ketut Suwetja ${ }^{2}$ dan Lita A.D.Y. Montolalu ${ }^{2}$ \\ ${ }^{1)}$ Mahasiswa pada Program Studi Teknologi Hasil Perikanan FPIK Unsrat Manado \\ ${ }^{2)}$ Staf pengajar pada Program Studi Teknologi Hasil Perikanan FPIK Unsrat Manado \\ Email: destaekasari@yahoo.com
}

\begin{abstract}
The skipjack tuna (Katsuwonus pelamis-L) or the locally known as Cakalang and the mackerel tuna (Euthynnus affinis) or tongkol as it known locally are the types of fishes that have high economic value. The aim of this research is to observe the decrease in freshness quality of the skipjack tuna and the mackerel tuna that have been stored for 14 days in a cool box with the temperature of $0-5^{\circ} \mathrm{C}$, with the supporting data based on The TVB-N analysis, organoleptic analysis and Miogobin value analysis. The results using the three testing procedures which are consists of TVB-N value, organoleptic value and Mioglobin value, indicated that the meat of the mackarel tuna have more faster rate of degradation than the skipjack tuna. Data from the result of TVB-N anova calculation proved that the type of fish have no influence on the TVB-N value, while the storage duration are very influential the TVB-N value. In data of organoleptic value the general impression of skipjack tuna and the mackerel tuna obtained from the anova calculated imply that the type of fish influence the appearance and texture but not with the eyes gills and odour. While the treatment of storage time are impacted greatly on the appearance, texture as well as gills and odour.
\end{abstract}

\begin{abstract}
Keyword: $\quad T V B-N$, Organoleptic, Mioglobin.
Ikan cakalang(Katsuwonus pelamis-L) dan ikan tongkol (Euthynnus affinis) merupakan salah satu jenis ikan yang mempunyai nilai ekonomi tinggi. Tujuan penelitian ini yakni untuk melihat kemunduran mutu kesegaran ikan cakalang dan ikan tongkol yang disimpan selama 14 hari dengan suhu $0-5^{\circ} \mathrm{C}$ di cool box. Metode yang digunakan yaitu analisa TVB-N, analisa organoleptik dan analisa nilai Miogobin sebagai pendukung. Hasil analisa dengan tiga metode uji yaitu nilai TVB-N, nilai organoleptik dan nilai mioglobin, semuanya mengatakan bahwa daging ikan tongkol lebih cepat terdegradasi dibandingkan dengan ikan cakalang. Data hasil perhitungan anova TVB-N menyatakan bahwa jenis ikan tidak mempengaruhi kadar TVB-N sedangkan waktu lama penyimpanan sangat mempengaruhi tingkat kadar TVBN. Pada data nilai organoleptik kesan umum ikan cakalang dan ikan tongkol pada hasil perhitungan anova didapatkan jenis ikan mempengaruhi kenampakan dan tekstur tetapi tidak untuk mata, insang dan bau Sedangkan untuk perlakuan lama penyimpanan sangat mempengaruhi pada kenampakan, tekstur, insang, mata dan bau.
\end{abstract}

Kata Kunci: $T V B-N$, Organoleptik, Mioglobin.

\section{PENDAHULUAN}

Ikan memiliki komposisi kimia, yang bermanfaat bagi tubuh manusia. Secara garis besar ikan mengandung air $(65-80 \%)$, protein $17-22 \%)$, lemak $(0,5-2 \%)$ dan abu $(1-2 \%)$. Murray et al. (2001) dalam Yanuar (2015).

Salah satu faktor yang menentukan nilai jual ikan dan hasil perikanan lain adalah tingkat kesegarannya (Junianto, 2003). Mutu kesegaran dapat mencakup rupa atau kenampakan, rasa, bau dan juga tekstur yang secara sadar ataupun tidak sadar akan dinilai oleh pembeli atau pengguna dari produk tersebut (Winarni $d k k$. 2003).
Ikan yang sudah mati mengalami pembusukan yang sangat cepat setelah tertangkap kecuali ditangani dengan baik. Suhu yang tinggi mempercepat dan memperpendek rigormotis dan mengantarnya ke proses autolysis dan pembusukan oleh bakteri yang berjalan sangat cepat (Murniati dan Sunarman, 2000).

Aksi enzim dan bakteri mengurai komponen penyusun jaringan tubuh ikan sehingga menghasilkan perubahan fisik seperti daging ikan menjadi lunak dan perubahan kimia yang menghasilkan senyawa yang mudah menguap dan berbau busuk (Hadiwiyoto, 1993). Senyawa yang mudah menguap memberi kesan 
ikan telah menjadi busuk, sehingga senyawasenyawa ini dipakai sebagai indeks kemunduran mutu ikan. Kadar senyawa menguap ini dapat ditentukan secara laboratorum yang disebut dengan penentuan kadar TVB-N Suwetja, (1993).

\section{METODOLOGI PENELITIAN}

\section{Tata Laksana Penelitian}

- Ikan cakalang dan tongkol akan dibeli dari TPI Tumumpa dimasukan ke dalam cool box dengan perbandingan es dan ikan 2:1;

- Dibawa ke Laboratorium Pengendalian Mutu Hasil Perikanan;

- Ikan yang akan diteliti disendirikan dan lainnya tetap disimpan dalam cool box dengan suhu $0-5^{\circ} \mathrm{C}$;

- Siapkan nampan berisikan air dingin dan es kemudian masukan ikan yang akan diuji organoleptik;

- Setelah selesai uji organoleptik, ikan diambil daging bagian ekor, tengah dan dekat kepala.

\section{Parameter Yang Dianalisis}

Nilai-TVB-N (Suwetja, 1993) berikut:

Cara pelaksanaan TVB-N yaitu sebagai

1. Timbang sampel sebanyak 5 gram.

2. Haluskan sampel dan tambahkan $10 \mathrm{ml}$ TCA homogenkan dalam mortar, kemudian diamkan \pm 30 menit (sampai dapatan agak terpisah).

3. Siapkan cawan Conway, olesi dengan vaselin.

4. Masukan $1 \mathrm{ml} \mathrm{H}_{3} \mathrm{BO}_{3}$ dan 2 tetes indikator di bagian tengah cawan Conway.

5. Dibagian luar cawan Conway masukan $1 \mathrm{ml}$ ekstrak sampel kemudian ditutup dengan bagian sedikit terbuka dan beri $1 \mathrm{ml}$ larutan $\left(\mathrm{K}_{2} \mathrm{CO}_{3}\right)$ dan tutup rapat.

6. Putar-putar cawan conway beberapa kali dengan berlahan supaya sampel dan larutan potassium karbonat $\left(\mathrm{K}_{2} \mathrm{CO}_{3}\right)$ dapat tercampur.

7. Pada blangko larutan ekstras sampel daging ikan diganti dengan larutan TCA.

8. Lalu simpan pada inkubator dengan suhu $37^{\circ} \mathrm{C}$ selama 80 menit atau pada suhu kamar selama 24 jam.

9. Titrasi dengan larutan asam klorida $(\mathrm{HCl})$ encer.

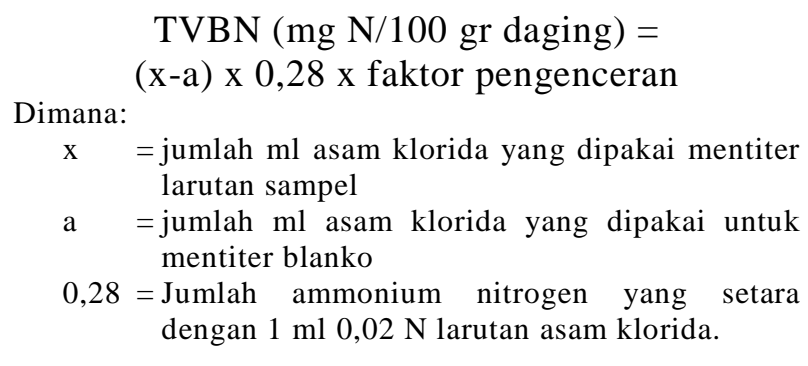

Nilai Organoleptik (BSN 2006)

Panelis yang digunakan sebanyak 15-20 orang panelis semi terlatih. Penilain uji organoleptik meliputi kenampakan, tekstur, bau, insang dan mata dianalisa menggunakan lembar skor dengan skala organoleptic. Untuk setiap panelis disediakan lembar penilaian, cara penilaiannya ialah dengan memberikan tanda $\sqrt{ }$ pada kolom yang tersedia sesuai tingkat kesukaan. Data yang diperoleh dari lembar skor dalam bentuk angka untuk selanjutnya dianalisis.

Nilai-Mioglobin (Bito 1964) dimofikasi oleh Suwetja 1992 sbb:

1. Sampel ditimbang sebanyak 10 gram.

2. Sampel dihaluskan.

3. Masukan dalam beker glass dan diberi aquades dingin sebanyak $30 \mathrm{ml}$ diamkan sebentar.

4. Larutan ekstrak yang dihasilkn disaring dengan menggunakan kertas saring no 42 di dalam refrigerator.

5. Supernatannya dimasukan ke dalam gelas cell untuk dibaca optikal densita pada spektrofotometer dengan panjang gelombang OD pada $540 \mathrm{~nm}$ dan OD pada $503 \mathrm{~nm}$.

6. Sebelum ekstrak dimasukkan ke dalam spektrofotometer perlu diamati absorbansi blanko, berupa air suling (Bito, 1964 dan Suwetja, 1992).

Dengan demikian dapat dirumuskan:

$$
\text { Nilai-Mb }=\frac{\text { OD pada } 540 \mathrm{~nm}}{\text { OD pada } 503 \mathrm{~nm}}
$$

\section{HASIL DAN PEMBAHASAN}

Berdasarkan data di bawah ini dapat dilihat bahwa nilai rata-rata TVB-N tertinggi adalah 43,29 pada ikan tongkol penyimpanan hari ke 14 , sedangkan nilai rata-rata TVB-N terendah adalah 9,24 pada ikan cakalang penyimpanan hari ke 0 .

Rumus: 
Tabel 1. Data nilai TVB-N pada perlakuan jenis ikan dan lama penyimpanan.

\begin{tabular}{|c|c|c|c|c|c|}
\hline \multirow[b]{2}{*}{$\begin{array}{c}\text { Perlakuan } \\
\text { Jenis Ikan } \\
\text { (A) }\end{array}$} & \multirow{2}{*}{$\begin{array}{c}\text { Perlakuan } \\
\text { Lama } \\
\text { Penyimpanan } \\
\text { (B) } \\
\end{array}$} & \multicolumn{2}{|c|}{ TVB-N } & \multirow[b]{2}{*}{ Total } & \multirow[b]{2}{*}{$\begin{array}{l}\text { Rata- } \\
\text { Rata }\end{array}$} \\
\hline & & I & II & & \\
\hline \multirow{8}{*}{$\begin{array}{l}\text { Ikan } \\
\text { Cakalang } \\
\text { (A1) }\end{array}$} & 0 & 10.08 & 8.4 & 18.48 & 9.24 \\
\hline & 2 & 11.76 & 10.92 & 22.68 & 11.34 \\
\hline & 4 & 13.44 & 14.28 & 27.72 & 13.86 \\
\hline & 6 & 18.48 & 20.16 & 38.64 & 19.32 \\
\hline & 8 & 25.2 & 27.72 & 52.92 & 26.46 \\
\hline & 10 & 30.24 & 28.08 & 58.32 & 29.16 \\
\hline & 12 & 31.92 & 33.6 & 65.52 & 32.76 \\
\hline & 14 & 41.23 & 40.32 & 81.55 & 40.77 \\
\hline \multirow{8}{*}{$\begin{array}{c}\text { Ikan } \\
\text { Tongkol } \\
\text { (A2) }\end{array}$} & 0 & 9.24 & 10.92 & 20.16 & 10.08 \\
\hline & 2 & 12.06 & 10.92 & 22.98 & 11.49 \\
\hline & 4 & 15.12 & 13.44 & 28.56 & 14.28 \\
\hline & 6 & 19.32 & 18.46 & 37.78 & 18.89 \\
\hline & 8 & 27.04 & 29.4 & 56.44 & 28.22 \\
\hline & 10 & 29.6 & 31.43 & 61.03 & 30.51 \\
\hline & 12 & 30.24 & 37.8 & 68.04 & 34.02 \\
\hline & 14 & 44.58 & 42 & 86.58 & 43.29 \\
\hline
\end{tabular}

Dari data di atas dapat dilihat bahwa perlakuan jenis ikan cakalang mempunyai mutu lebih baik dari pada ikan tongkol. Untuk mengetahui pengaruh perlakuan (A) dan lama penyimpanan (B) terhadap nilai TVB-N, maka dilakukan analisa sidik ragam berikut ini:

Tabel 2. Sidik ragam peningkatan TVB-N untuk perlakuan jenis ikan dan lama penyimpanan.

\begin{tabular}{lrrrrrr}
\hline \multirow{2}{*}{$(\mathbf{S K})$} & \multirow{2}{*}{$(\mathbf{D B})$} & \multicolumn{2}{c}{$(\mathbf{J K})$} & \multirow{2}{*}{$(\mathbf{K}$ ) $)$} & \multirow{2}{*}{ F.Hit } & \multicolumn{2}{c}{ F.Tabel } \\
\cline { 6 - 7 } Perlakuan & 15 & $3.781,31$ & 252,09 & $78,98^{* *}$ & $\mathbf{0 , 0 5}$ & $\mathbf{0 , 0 1}$ \\
Kelompok & 1 & 2,15 & 2,15 & $0,67^{\text {th }}$ & 4,49 & 8,52 \\
$(\mathbf{A})$ & 1 & 7,74 & 7,74 & $2,428^{\text {th }}$ & 4,49 & 8,53 \\
$(\mathbf{B})$ & 7 & $3.767,37$ & 538,20 & $168,62^{* *}$ & 2,66 & 4,03 \\
$(\mathbf{A} \times \mathbf{B})$ & 7 & 6,19 & 0,88 & $0,28^{\text {th }}$ & 2,66 & 4,03 \\
Galat & 16 & 51,07 & 3,19 & & & \\
Total & 32 & & & & &
\end{tabular}

Keterangan:

$(\mathrm{SK})$ : Sumber Keragaman

(DB) : Derajat Bebas

(JK) : Jumlah Kuadrat

(KT) : Kuadrat Tengah

(A) : Jenis Ikan cakalang dan Ikan Tongkol

(B) : Lama Penyimpanan

$(\mathrm{A} \times \mathrm{B})$ : Jenis Ikan dan Lama penyimpanan

** : Berbeda Sangat Nyata

tn : Berbeda Tidak Nyata

Berdasarkan hasil sidik ragam di atas peningkatan TVB-N untuk perlakuan jenis ikan memberikan pengaruh yang tidak nyata $(\mathrm{P}<0,01$ dan 0,05) sedangkan untuk perlakuan lama penyimpanan memberikan pengaruh yang sangat berbeda nyata $(\mathrm{P}>0,01$ dan 0,05$)$. Dari data tersebut maka perlu untuk dilakukan uji lanjut untuk perlakuan lama penyimpanan.

Histogram nilai TVB-N ikan cakalang dan ikan tongkol selama penyimpanan dapat dilihat di bawah ini.

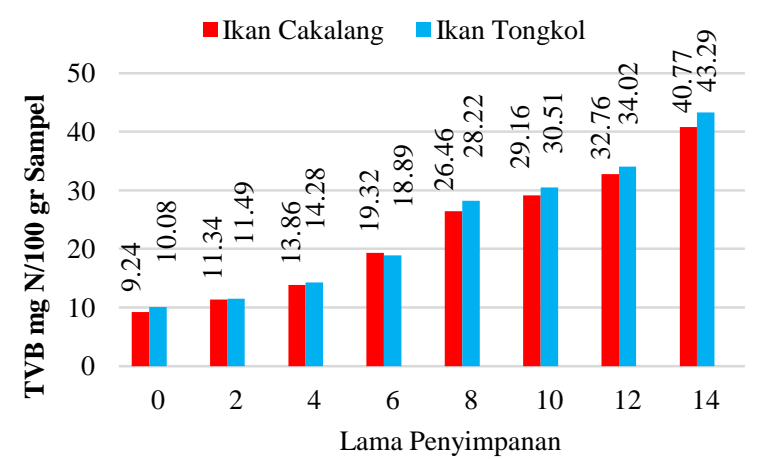

Gambar 1. Histogram nilai TVB-N ikan cakalang dan ikan tongkol selama penyimpanan.

Dari gambar diatas menunjukan bahwa secara keseluruhan terjadi kenaikan nilai TVB$\mathrm{N}$ pada semua jenis ikan dari hari ke 0 sampai hari ke 14. Di dukung oleh pernyataan Suryaningrum dan Irianto, (2003) dalam Suwetja, (2013) batas nilai kesegaran bakterial dengan uji kadar TVB-N sebesar $30 \mathrm{mg} \mathrm{N} / 100$ $\mathrm{g}$ daging pada hasil-hasil perikanan (ikan dan shellfish). Menurut Ozogul (1999) dalam Nurjanah $d k k,(2011)$, peningkatan nilai TVB-N disebabkan oleh aktivitas autolisis dan kegiatan bakteri pembusuk selama proses penyimpanan.

\begin{tabular}{|c|c|c|c|c|c|}
\hline \multicolumn{6}{|c|}{$\begin{array}{l}\text { Nilai Organoleptik } \\
\text { Kenampakan }\end{array}$} \\
\hline \multirow{2}{*}{$\begin{array}{c}\text { Perlakuan } \\
\text { Jenis Ikan } \\
\text { (A) }\end{array}$} & \multirow{2}{*}{$\begin{array}{c}\text { Perlakuan } \\
\text { Lama } \\
\text { Penyimpanan } \\
\text { (B) }\end{array}$} & \multicolumn{2}{|c|}{ Kenampakan } & \multirow[b]{2}{*}{ Total } & \multirow[b]{2}{*}{$\begin{array}{l}\text { Rata- } \\
\text { Rata }\end{array}$} \\
\hline & & I & II & & \\
\hline \multirow{8}{*}{$\begin{array}{c}\text { Ikan } \\
\text { Cakalang } \\
\text { (A1) }\end{array}$} & 0 & 9,00 & 9,00 & 18,00 & 9,00 \\
\hline & 2 & 7,67 & 8,33 & 16,00 & 8,00 \\
\hline & 4 & 7,00 & 6,6 & 13,6 & 6,8 , \\
\hline & 6 & 5,53 & 7,4 & 12,93 & 6,47 \\
\hline & 8 & 6,07 & 6,47 & 12,53 & 6,27 \\
\hline & 10 & 4,60 & 4,73 & 9,33 & 4,67 \\
\hline & 12 & 4,47 & 4,07 & 8,53 & 4,27 \\
\hline & 14 & 3,27 & 3,4 & 6,67 & 3,33 \\
\hline \multirow{8}{*}{$\begin{array}{l}\text { Ikan } \\
\text { Tongkol } \\
\text { (A2) }\end{array}$} & 0 & 9,00 & 9,00 & 18,00 & 9,00 \\
\hline & 2 & 7,00 & 7,40 & 14,40 & 7,2 \\
\hline & 4 & 6,47 & 7,27 & 13,73 & 6,87 \\
\hline & 6 & 6,07 & 6,47 & 12,53 & 6,27 \\
\hline & 8 & 5,27 & 4,73 & 10,00 & 5,00 \\
\hline & 10 & 4,60 & 4,60 & 9,20 & 4,60 \\
\hline & 12 & 3,93 & 3,27 & 7,20 & 3,60 \\
\hline & 14 & 3,27 & 3,27 & 6,53 & 3,27 \\
\hline
\end{tabular}

Dari data di atas ini dapat dilihat nilai rata-rata organoleptik untuk kenampakan yang tertinggi adalah 9 yang memiliki ciri-ciri (Sayatan daging sangat cemerlang, spesifikasi jenis, tidak ada pemerahan sepanjang tulang belakang, dinding perut perut utuh) terdapat pada ikan cakalang dan ikan tongkol pada hari ke 0 . Nilai rata-rata terendah terdapat pada ikan tongkol 3,27 dengan ciri-ciri (Sayatan daging 
kusam, warna merah jelas sekali sepanjang tulang belakang, dinding perut lunak) pada ikan tongkol hari ke 14.

Untuk mengetahui pengaruh perlakuan jenis ikan (A) dan perlakuan lama penyimpanan (B) terhadap nilai organoleptik kenampakan, maka dilakukan analisis sidik ragam yang hasilnya dapat dilihat pada tabel berikut ini:

\begin{tabular}{|c|c|c|c|c|c|c|}
\hline \multirow{2}{*}{ (SK) } & \multirow{2}{*}{ (DB) } & \multirow{2}{*}{ (JK) } & \multirow{2}{*}{$(\mathbf{K T})$} & \multirow{2}{*}{ F.Hit } & \multicolumn{2}{|c|}{ F.Tabel } \\
\hline & & & & & $\mathbf{0 , 0 5}$ & $\mathbf{0 , 0 1}$ \\
\hline Perlakuan & 15 & 106,31 & 7,09 & $36,98 * *$ & 2,40 & 3,52 \\
\hline Kelompok & 1 & 0,245 & 0,245 & $0,28^{\mathrm{tn}}$ & 4,49 & 8,53 \\
\hline (A) & 1 & 1,125 & 1,125 & $5,87 *$ & 4,49 & 8,53 \\
\hline (B) & 7 & 103,56 & 14,79 & $77,19 * *$ & 2,66 & 4,03 \\
\hline$(\mathbf{A} \times \mathbf{B})$ & 7 & 1,62 & 0,23 & $1,20^{\mathrm{tn}}$ & 2,66 & 4,03 \\
\hline Galat & 16 & 3 & 0,19 & & & \\
\hline Total & 32 & & & & & \\
\hline \multicolumn{7}{|l|}{ Keterangan: } \\
\hline$(\mathrm{SK})$ & \multicolumn{6}{|c|}{ : Sumber Keragaman } \\
\hline (DB) & \multicolumn{6}{|c|}{ Derajat Bebas } \\
\hline$(\mathrm{JK})$ & \multicolumn{6}{|c|}{ Jumlah Kuadrat } \\
\hline$(\mathrm{KT})$ & \multicolumn{6}{|c|}{ Kuadrat Tengah } \\
\hline (A) & \multicolumn{6}{|c|}{ Jenis Ikan cakalang dan Ikan Tongkol } \\
\hline (B) & \multicolumn{6}{|c|}{ : Lama Penyimpanan } \\
\hline$(\mathrm{A} \times \mathrm{B})$ & \multicolumn{6}{|c|}{ Jenis Ikan dan Lama penyimpanan } \\
\hline$* *$ & \multicolumn{6}{|c|}{ Berbeda Sangat Nyata } \\
\hline$*$ & \multicolumn{6}{|c|}{ Berbeda Nyata } \\
\hline $\operatorname{tn}$ & \multicolumn{6}{|c|}{ Berbeda Tidak Nyata } \\
\hline
\end{tabular}

Hasil analisis sidik ragam di atas menunjukkan bahwa untuk perlakuan jenis ikan memberikan pengaruh yang nyata $(\mathrm{P}<0,01$ dan $>0,05)$ dan untuk perlakuan lama penyimpanan memberikan pengaruh yang berbeda sangat nyata $(\mathrm{P}>0,01$ dan 0,05$)$. Dari hasil tersebut maka dilakukan uji lanjut BNT .Berdasarkan hasil uji lanjut menujukan bahwa lama penyimpanan memberikan pengaruh yang berbeda sangat nyata.

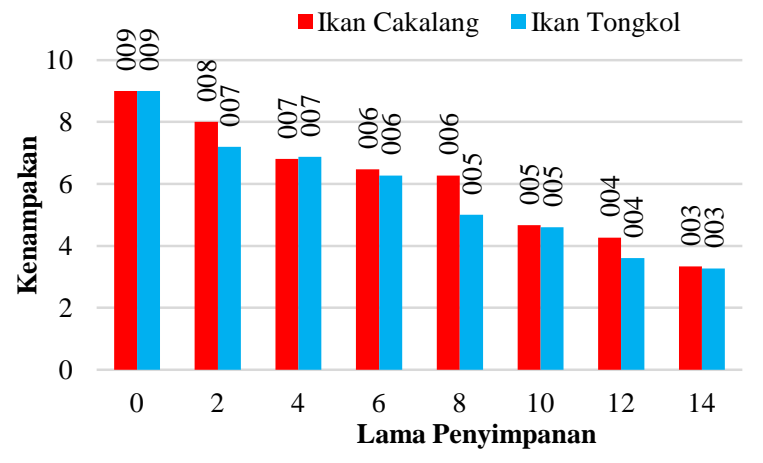

Pada gambar histogram di atas menunjukan bahwa nilai organoleptik kenampakan menurun dari hari k 2 sampai 14.

\section{Tekstur}

Dari data pada tabel di bawah ini dapat dilihat nilai rata-rata organoleptik untuk tekstur yang tertinggi adalah 9 yang memiliki ciri-ciri (Padat, elastis bila ditekan dengan jari) terdapat pada ikan cakalang dan ikan tongkol pada hari ke 0 . Nilai rata-rata terendah adalah 3 dengan ciri-ciri (Lunak, bekas jari terlihat bila ditekan) terdapat pada ikan tongkol hari ke 14.

\begin{tabular}{|c|c|c|c|c|c|}
\hline \multirow{2}{*}{$\begin{array}{c}\text { Perlakuan } \\
\text { Jenis Ikan } \\
\text { (A) }\end{array}$} & \multirow{2}{*}{$\begin{array}{c}\text { Perlakuan } \\
\text { Lama } \\
\text { Penyimpanan } \\
\text { (B) }\end{array}$} & \multicolumn{2}{|c|}{ Tekstur } & \multirow[b]{2}{*}{ Total } & \multirow{2}{*}{$\begin{array}{l}\text { Rata- } \\
\text { Rata }\end{array}$} \\
\hline & & I & II & & \\
\hline \multirow{8}{*}{$\begin{array}{l}\text { Ikan } \\
\text { Cakalang } \\
\text { (A1) }\end{array}$} & 0 & 9 & 9 & 18 & 9 \\
\hline & 2 & 7.27 & 7.93 & 15.2 & 7.6 \\
\hline & 4 & 6.2 & 7 & 13.2 & 6.6 \\
\hline & 6 & 6.47 & 6.73 & 13.2 & 6.6 \\
\hline & 8 & 5.13 & 4.87 & 10 & 5 \\
\hline & 10 & 4.73 & 4.33 & 9.07 & 4.53 \\
\hline & 12 & 3.93 & 3.8 & 7.73 & 3.87 \\
\hline & 14 & 3 & 3.13 & 6.13 & 3.07 \\
\hline \multirow{8}{*}{$\begin{array}{c}\text { Ikan } \\
\text { Tongkol } \\
\text { (A2) }\end{array}$} & 0 & 9 & 9 & 18 & 9 \\
\hline & 2 & 7.4 & 7.13 & 14.53 & 7.27 \\
\hline & 4 & 5.93 & 7.27 & 13.2 & 6.6 \\
\hline & 6 & 5.8 & 5.53 & 11.33 & 5.67 \\
\hline & 8 & 5 & 4.2 & 9.2 & 4.6 \\
\hline & 10 & 3.8 & 4.07 & 7.87 & 3.93 \\
\hline & 12 & 3.67 & 3.53 & 7.2 & 3.6 \\
\hline & 14 & 3.27 & 2.73 & 6 & 3 \\
\hline
\end{tabular}

Untuk mengetahui pengaruh perlakuan jenis ikan (A) dan perlakuan lama penyimpanan (B) terhadap nilai organoleptik tekstur, maka dilakukan analisis sidik ragam yang hasilnya dapat dilihat berikut ini:

\begin{tabular}{|c|c|c|c|c|c|c|}
\hline \multirow{2}{*}{ (SK) } & \multirow{2}{*}{ (DB) } & \multirow{2}{*}{ (JK) } & \multirow{2}{*}{$(\mathbf{K T})$} & \multirow{2}{*}{ F.Hit } & \multicolumn{2}{|c|}{ F.Tabel } \\
\hline & & & & & $\mathbf{0 , 0 5}$ & $\mathbf{0 , 0 1}$ \\
\hline Perlakuan & 15 & 116.71 & 7.78 & $57.16^{* *}$ & 2.40 & 3.52 \\
\hline Kelompok & 1 & 0.014 & 0.014 & $0.10^{\mathrm{tn}}$ & 4.49 & 8.58 \\
\hline (A) & 1 & 0.84 & 0.84 & $6.21 *$ & 4.49 & 8.53 \\
\hline (B) & 7 & 115.13 & 16.45 & $120.83 * *$ & 2.66 & 4.03 \\
\hline$(\mathbf{A} \times \mathbf{B})$ & 7 & 0.73 & 0.10 & $0.77^{\mathrm{tn}}$ & 2.66 & 4.03 \\
\hline Galat & 16 & 2 & 0.14 & & & \\
\hline Total & 32 & & & & & \\
\hline \multicolumn{7}{|l|}{ Keterangan: } \\
\hline$(\mathrm{SK})$ & \multicolumn{6}{|c|}{ : Sumber Keragaman } \\
\hline (DB) & \multicolumn{6}{|c|}{ : Derajat Bebas } \\
\hline$(\mathrm{JK})$ & \multicolumn{6}{|c|}{ : Jumlah Kuadrat } \\
\hline$(\mathrm{KT})$ & \multicolumn{6}{|c|}{ : Kuadrat Tengah } \\
\hline (A) & \multicolumn{6}{|c|}{ : Jenis Ikan cakalang dan Ikan Tongkol } \\
\hline (B) & \multicolumn{6}{|c|}{ : Lama Penyimpanan } \\
\hline$(\mathrm{A} \times \mathrm{B})$ & \multicolumn{6}{|c|}{ : Jenis Ikan dan Lama penyimpanan } \\
\hline$* *$ & \multicolumn{6}{|c|}{ : Berbeda Sangat Nyata } \\
\hline$*$ & \multicolumn{6}{|c|}{ : Berbeda Nyata } \\
\hline $\operatorname{tn}$ & \multicolumn{6}{|c|}{ : Berbeda Tidak Nyata } \\
\hline
\end{tabular}

Hasil analisis sidik ragam diatas menunjukan bahwa untuk perlakuan jenis ikan memberikan pengaruh yang nyata $(\mathrm{P}<0,01$ dan $>0,05)$ dan untuk perlakuan lama penyimpanan memberikan pengaruh yang berbeda sangat nyata $(\mathrm{P}>0,010,05)$. Dari hasil tersebut maka dilakukan uji lanjut BNT .Berdasarkan hasil uji lanjut menujukan bahwa lama penyimpanan memberikan pengaruh yang berbeda sangat nyata. 


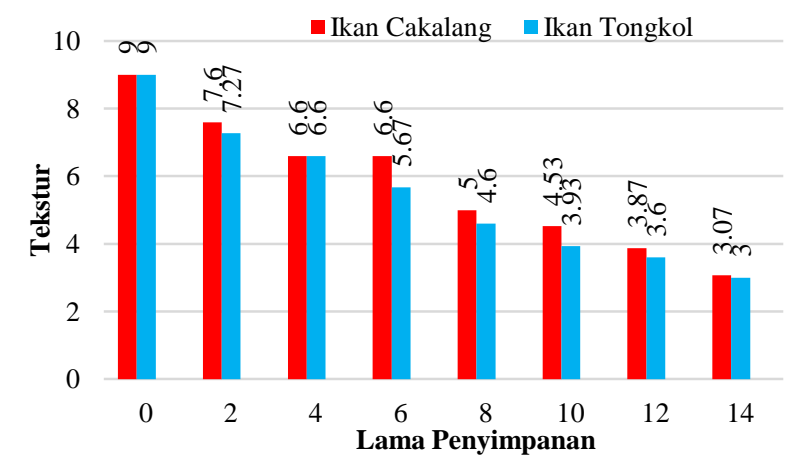

Pada gambar histogram diatas menunjukan bahwa nilai organoleptik tekstur menurun dari hari k 2 sampai 14. Hal ini disebabkan karena selama masa penyimpanan perubahan tekstur daging ikan akan berubah karena adanya pertumbuhan bakteri yang mengakibatkan daging ikan cakalang dan ikan tongkol sudah tidak bagus lagi. Menurut Suwetja, (2011) penguraian oleh bakteri mulai berlangsung insentif setelah tahap rigormortis berlalu, yaitu setelah daging ikan tidak lagi kompak. Pada penelitian sebelumnya Pianusa, (2016) mendapatkan nilai 7,03 pada penyimpanan 6 hari yaitu dengan kreteria (Agak padat, agak elastisbila ditekan dengan jari). Pada BSN, (2006) batas ambang/minimal organoleptik yaitu 7. Menurut Berhimpon dkk (2002) pada uji organoleptik ada 3 jenis kelas mutu yaitu mutu kelas 1 nilai $<8$, kelas 2 nilai $<7$ dan kelas 3 nilai $<5$.

\begin{tabular}{|c|c|c|c|c|c|}
\hline \multicolumn{6}{|l|}{ Bau } \\
\hline \multirow{2}{*}{$\begin{array}{c}\text { Perlakuan } \\
\text { Jenis Ikan } \\
\text { (A) }\end{array}$} & \multirow{2}{*}{$\begin{array}{c}\text { Perlakuan } \\
\text { Lama } \\
\text { Penyimpanan } \\
\text { (B) }\end{array}$} & \multicolumn{2}{|c|}{ Bau } & \multirow[b]{2}{*}{ Total } & \multirow[b]{2}{*}{$\begin{array}{l}\text { Rata- } \\
\text { Rata }\end{array}$} \\
\hline & & I & II & & \\
\hline \multirow{8}{*}{$\begin{array}{c}\text { Ikan } \\
\text { Cakalang } \\
\text { (A1) }\end{array}$} & 0 & 9 & 9 & 18.00 & 9 \\
\hline & 2 & 6.47 & 7.53 & 14 & 7 \\
\hline & 4 & 5.53 & 6.6 & 12.13 & 6.07 \\
\hline & 6 & 4.87 & 6.07 & 10.93 & 5.47 \\
\hline & $\begin{array}{l}0 \\
8\end{array}$ & 3.93 & 3.93 & 7.87 & 3.93 \\
\hline & 10 & 4.73 & 3 & 7.73 & 3.87 \\
\hline & 12 & 3.67 & 3.27 & 6.93 & 3.47 \\
\hline & 14 & 3.4 & 3.27 & 6.67 & 3.33 \\
\hline \multirow{8}{*}{$\begin{array}{c}\text { Ikan } \\
\text { Tongkol } \\
\text { (A2) }\end{array}$} & 0 & 9 & 9 & 18 & 9 \\
\hline & 2 & 6.33 & 7.13 & 13.47 & 6.73 \\
\hline & 4 & 5.4 & 5.93 & 11.33 & 5.67 \\
\hline & 6 & 5.4 & 4.6 & 10 & 5 \\
\hline & 8 & 3.53 & 3.4 & 6.93 & 3.47 \\
\hline & 10 & 3.27 & 3.4 & 6.67 & 3.33 \\
\hline & 12 & 3.93 & 2.33 & 6.27 & 3.13 \\
\hline & 14 & 3.27 & 2.6 & 5.87 & 2.93 \\
\hline
\end{tabular}

Hasil pengujian organoleptik bau ikan cakalang dan ikan tongkol selama 0 hari, 2 hari, 4 hari, 6 hari, 8 hari, 10 hari, 12 hari dan 14 hari pada penyimpanan dingin dalam cool box dapat dilihat pada (tabel 4). Dari data yang ada dapat dilihat nilai rata-rata organoleptik untuk bau yang tertinggi adalah 9 (Bau sangat segar, spesifik jenis) terdapat pada ikan cakalang dan ikan tongkol pada hari ke 0 . Nilai rata-rata terendah adalah 2,93 dengan ciri-ciri (Bau amoniak kuat, ada bau $\mathrm{H} 2 \mathrm{~S}$, bau asam jelas dan busuk)terdapat pada ikan tongkol hari ke 14 .

Untuk mengetahui pengaruh perlakuan jenis ikan (A) dan perlakuan lama penyimpanan (B) terhadap nilai organoleptik bau, maka dilakukan analisis sidik ragam yang hasilnya dapat dilihat berikut ini:

\begin{tabular}{|c|c|c|c|c|c|c|}
\hline \multirow{2}{*}{ (SK) } & \multirow{2}{*}{ (DB) } & \multirow{2}{*}{$(\mathbf{J K})$} & \multirow{2}{*}{$(\mathbf{K T})$} & \multirow{2}{*}{ F.Hit } & \multicolumn{2}{|c|}{ F.Tabel } \\
\hline & & & & & $\mathbf{0 , 0 5}$ & $\mathbf{0 , 0 1}$ \\
\hline Perlakuan & 15 & 122.23 & 8.15 & $22.67 * *$ & 2.40 & 3.52 \\
\hline Kelompok & 1 & 0.014 & 0.014 & 0.039 & 4.49 & 8.53 \\
\hline (A) & 1 & 1.03 & 1.03 & $2.86^{\mathrm{tn}}$ & 4.49 & 8.53 \\
\hline (B) & 7 & 121.01 & 17.29 & $48.09 * *$ & 2.66 & 4.03 \\
\hline$(\mathbf{A} \times \mathbf{B})$ & 7 & 0.19 & 0.03 & $0.08^{\mathrm{tn}}$ & 2.66 & 4.03 \\
\hline Galat & 16 & 6 & 0.36 & & & \\
\hline Total & 32 & & & & & \\
\hline \multicolumn{7}{|l|}{ Keterangan: } \\
\hline$(\mathrm{SK})$ & \multicolumn{6}{|c|}{ Sumber Keragaman } \\
\hline (DB) & \multicolumn{6}{|c|}{ Derajat Bebas } \\
\hline$(\mathrm{JK})$ & \multicolumn{6}{|c|}{ Jumlah Kuadrat } \\
\hline$(\mathrm{KT})$ & \multicolumn{6}{|c|}{ Kuadrat Tengah } \\
\hline (A) & \multicolumn{6}{|c|}{ Jenis Ikan cakalang dan Ikan Tongkol } \\
\hline (B) & \multicolumn{6}{|c|}{ Lama Penyimpanan } \\
\hline$(\mathrm{A} \times \mathrm{B})$ & \multicolumn{6}{|c|}{ Jenis Ikan dan Lama penyimpanan } \\
\hline$* *$ & \multicolumn{6}{|c|}{ Berbeda Sangat Nyata } \\
\hline tn & \multicolumn{6}{|c|}{ Berbeda Tidak Nyata } \\
\hline
\end{tabular}

Hasil analisis sidik ragam diatas menunjukan bahwa untuk perlakuan jenis ikan memberikan pengaruh yang tidak nyata $(\mathrm{P}<$ 0,01 dan 0,05) dan untuk perlakuan lama penyimpanan memberikan pengaruh yang berbeda sangat nyata $(P>0,010,05)$. Dari hasil tersebut maka dilakukan uji lanjut BNT. Berdasarkan hasil uji lanjut menujukan bahwa lama penyimpanan memberikan pengaruh yang berbeda sangat nyata.

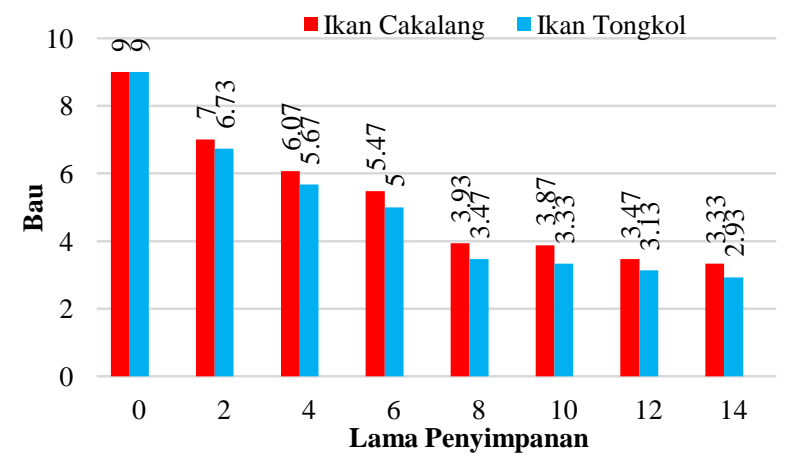

Pada gambar histogram di atas menunjukan bahwa nilai organoleptik bau menurun dari hari k 2 sampai 14. Menurut Junianto (2003), perubahan yang terjadi pada bau ikan karena penguraian protein dari 
aktivitas bakteri, sehingga hubungan antara jumlah bakteri dengan bau ikan berbanding lurus. Pada penelitian sebelumnya yang dilakukan Pianusa, (2016) mendapatkan nilai 7,13 pada penyimpanan hari ke 6 dengan kreteria (Netral). pada BSN, (2016) batas ambang nilai organoleptik bau yaitu 7. Menurut Berhimpon dkk (2002) pada uji organoleptik ada 3 jenis kelas mutu yaitu mutu kelas 1 nilai $<8$, kelas 2 nilai $<7$ dan kelas 3 nilai $<5$.

\section{Insang}

Dari data tabel dibawah ini dapat dilihat nilai rata-rata organoleptik untuk insang yang tertinggi adalah 9 dengan ciri-ciri (Warna merah cemerlang, tanpa lender) terdapat pada ikan cakalang dan ikan tongkol pada hari ke 0 . Nilai rata-rata terendah adalah 2,33 dengan ciriciri (Marna merah coklat, lender tebal) terdapat pada ikan tongkol hari ke 12.

\begin{tabular}{|c|c|c|c|c|c|}
\hline \multirow{2}{*}{$\begin{array}{l}\text { Perlakuan } \\
\text { Jenis Ikan } \\
\text { (A) }\end{array}$} & \multirow{2}{*}{$\begin{array}{c}\text { Perlakuan } \\
\text { Lama } \\
\text { Penyimpanan } \\
\text { (B) }\end{array}$} & \multicolumn{2}{|c|}{ Insang } & \multirow{2}{*}{ Total } & \multirow{2}{*}{$\begin{array}{l}\text { Rata- } \\
\text { Rata }\end{array}$} \\
\hline & & I & II & & \\
\hline \multirow{8}{*}{$\begin{array}{c}\text { Ikan } \\
\text { Cakalang } \\
\text { (A1) }\end{array}$} & 0 & 9 & 9 & 18 & 9 \\
\hline & 2 & 7.13 & 7.67 & 14.8 & 7.4 \\
\hline & 4 & 6.27 & 6.47 & 12.73 & 6.37 \\
\hline & 6 & 5.13 & 7 & 12.13 & 6.07 \\
\hline & 8 & 5.4 & 3.8 & 9.2 & 4.6 \\
\hline & 10 & 4.6 & 3.53 & 8.13 & 4.07 \\
\hline & 12 & 3.4 & 3.8 & 7.2 & 3.6 \\
\hline & 14 & 3 & 3.67 & 6.67 & 3.33 \\
\hline \multirow{8}{*}{$\begin{array}{c}\text { Ikan } \\
\text { Tongkol } \\
\text { (A2) }\end{array}$} & 0 & 9 & 9 & 18 & 9 \\
\hline & 2 & 6.33 & 6.87 & 13.2 & 6.6 \\
\hline & 4 & 6.2 & 5.53 & 11.73 & 5.87 \\
\hline & 6 & 5.93 & 4.2 & 10.13 & 5.07 \\
\hline & 8 & 5.13 & 3.53 & 8.67 & 4.33 \\
\hline & 10 & 3.93 & 3.67 & 7.6 & 3.8 \\
\hline & 12 & 3.67 & 3.27 & 6.93 & 3.47 \\
\hline & 14 & 2.6 & 2.07 & 4.67 & 2.33 \\
\hline
\end{tabular}

Untuk mengetahui pengaruh perlakuan jenis ikan (A) dan perlakuan lama penyimpanan (B) terhadap nilai organoleptik insang, maka dilakukan analisis sidik ragam yang hasilnya dapat dilihat berikut ini:

\begin{tabular}{|c|c|c|c|c|c|c|}
\hline \multirow{2}{*}{ (SK) } & \multirow{2}{*}{ (DB) } & \multirow{2}{*}{ (JK) } & \multirow{2}{*}{$(\mathbf{K T})$} & \multirow{2}{*}{ F.Hit } & \multicolumn{2}{|c|}{ F.Tabel } \\
\hline & & & & & 0,05 & $\mathbf{0 , 0 1}$ \\
\hline Perlakuan & 15 & 119.39 & 7.96 & $17.07 * *$ & 2.40 & 3.52 \\
\hline Kelompok & 1 & 0.42 & 0.42 & $0.90^{\mathrm{tn}}$ & 4.49 & 8.53 \\
\hline (A) & 1 & 1.97 & 1.97 & $4.22^{\mathrm{tn}}$ & 4.49 & 8.53 \\
\hline (B) & 7 & 116.34 & 16.62 & $35.65 * *$ & 2.66 & 4.03 \\
\hline$(A \times B)$ & 7 & 1.08 & 0.15 & $0.33^{\text {th }}$ & 2.66 & 4.03 \\
\hline Galat & 16 & 7 & 0.47 & & & \\
\hline Total & 32 & & & & & \\
\hline \multicolumn{7}{|l|}{ Keterangan: } \\
\hline$(\mathrm{SK})$ & \multicolumn{6}{|c|}{ : Sumber Keragaman } \\
\hline (DB) & \multicolumn{6}{|c|}{ Derajat Bebas } \\
\hline$(\mathrm{JK})$ & \multicolumn{6}{|c|}{ Jumlah Kuadrat } \\
\hline$(\mathrm{KT})$ & \multicolumn{6}{|c|}{ Kuadrat Tengah } \\
\hline (A) & \multicolumn{6}{|c|}{ Jenis Ikan cakalang dan Ikan Tongkol } \\
\hline (B) & \multicolumn{6}{|c|}{ Lama Penyimpanan } \\
\hline$(\mathrm{A} \times \mathrm{B})$ & \multicolumn{6}{|c|}{ Jenis Ikan dan Lama penyimpanan } \\
\hline$* *$ & \multicolumn{6}{|c|}{ Berbeda Sangat Nyata } \\
\hline tn & \multicolumn{6}{|c|}{ Berbeda Tidak Nyata } \\
\hline
\end{tabular}

Hasil analisis sidik ragam diatas menunjukan bahwa untuk perlakuan jenis ikan memberikan pengaruh yang nyata $(\mathrm{P}<0,01$ dan $0,05)$ dan untuk perlakuan lama penyimpanan memberikan pengaruh yang berbeda sangat nyata $(\mathrm{P}>0,010,05)$. Dari hasil tersebut maka dilakukan uji lanjut BNT .Berdasarkan hasil uji lanjut menujukan bahwa lama penyimpanan memberikan pengaruh yang berbeda sangat nyata.

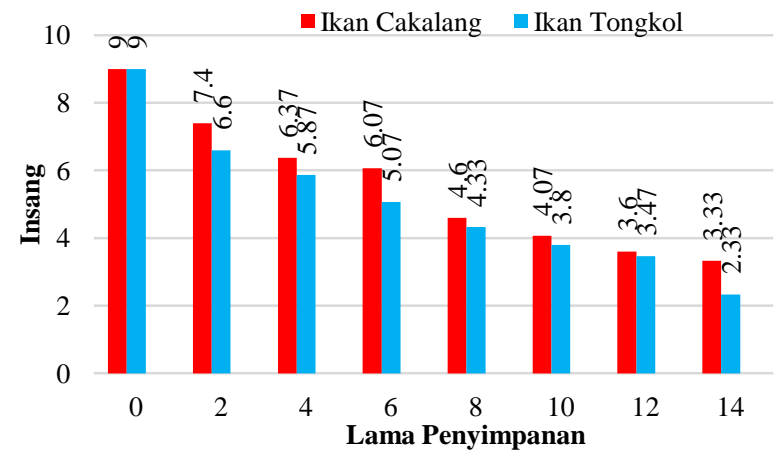

Pada gambar histogram di atas menunjukan bahwa nilai organoleptik insang menurun dari hari k 2 sampai 14. Semakin lama perlakuan penyimpanan maka insang ikan juga berubah, ikan segar memiliki warna insang merah cerah tetapi semakin lama penyimpanan warna insang akan memudar menjadi coklat, tampak agak berlendir dan bau asam lebih nyata Berhimpon, dkk (2002). Pada penelitian sebelumnya yang dilakukan oleh Pianusa, (2016) di dapatkan nilai 7,03 pada penyimpanan 6 hari dengan kreteria (Warna merah agak kusam, tanpa lender). Pada BSN, (2006) batas ambang untuk uji organoleptik insang yaitu 7. Menurut Berhimpon dkk (2002) pada uji organoleptik ada 3 jenis kelas mutu yaitu mutu kelas 1 nilai $<8$, kelas 2 nilai $<7$ dan kelas 3 nilai $<5$.

\section{Mata}

Dari data pada tabel dibawah ini dapat dilihat nilai rata-rata organoleptik untuk mata yang tertinggi adalah 9 dengan ciri-ciri (Cerah, bola mata menonjol, kornea jernih) terdapat pada ikan cakalang dan ikan tongkol pada hari ke 0 . Nilai rata-rata terendah adalah 2,4 dengan ciri-ciri (Bola mata cekung, pupil mulai berubah menjadi putih susu, kornea keruh) terdapat pada ikan tongkol hari ke 14 


\begin{tabular}{|c|c|c|c|c|c|}
\hline \multirow{2}{*}{$\begin{array}{c}\text { Perlakuan } \\
\text { Jenis Ikan } \\
\text { (A) }\end{array}$} & \multirow{2}{*}{$\begin{array}{c}\text { Perlakuan } \\
\text { Lama } \\
\text { Penyimpanan } \\
\text { (B) } \\
\end{array}$} & \multicolumn{2}{|c|}{ Mata } & \multirow[b]{2}{*}{ Total } & \multirow[b]{2}{*}{$\begin{array}{l}\text { Rata- } \\
\text { Rata }\end{array}$} \\
\hline & & I & II & & \\
\hline \multirow{8}{*}{$\begin{array}{c}\text { Ikan } \\
\text { Cakalang } \\
\text { (A1) }\end{array}$} & 0 & 9 & 9 & 18 & 9 \\
\hline & 2 & 8.47 & 7.8 & 16.27 & 8.13 \\
\hline & 4 & 7.27 & 7.67 & 14.93 & 7.47 \\
\hline & 6 & 5.8 & 6.2 & 12 & 6 \\
\hline & 8 & 5.27 & 5.13 & 10.4 & 5.2 \\
\hline & 10 & 4.07 & 3.53 & 7.6 & 3.8 \\
\hline & 12 & 3.4 & 2.47 & 5.87 & 2.93 \\
\hline & 14 & 3 & 2.07 & 5.07 & 2.53 \\
\hline \multirow{8}{*}{$\begin{array}{c}\text { Ikan } \\
\text { Tongkol } \\
\text { (A2) }\end{array}$} & 0 & 9 & 9 & 18 & 9 \\
\hline & 2 & 7.53 & 7.80 & 15.33 & 7.67 \\
\hline & 4 & 6.2 & 6.2 & 12.4 & 6.2 \\
\hline & 6 & 5 & 5.53 & 10.53 & 5.27 \\
\hline & 8 & 5.67 & 4.2 & 9.87 & 4.93 \\
\hline & 10 & 4.2 & 3.27 & 7.47 & 3.73 \\
\hline & 12 & 3.53 & 3.13 & 6.67 & 3.33 \\
\hline & 14 & 2.47 & 2.33 & 4.8 & 2.4 \\
\hline
\end{tabular}

Untuk mengetahui pengaruh perlakuan jenis ikan (A) dan perlakuan lama penyimpanan (B) terhadap nilai organoleptik mata, maka dilakukan analisis sidik ragam yang hasilnya dapat dilihat berikut ini:

\begin{tabular}{|c|c|c|c|c|c|c|}
\hline \multirow{2}{*}{ (SK) } & \multirow{2}{*}{ (DB) } & \multirow{2}{*}{$(\mathbf{J K})$} & \multirow{2}{*}{$(\mathrm{KT})$} & \multirow{2}{*}{ F.Hit } & \multicolumn{2}{|c|}{ F.Tabel } \\
\hline & & & & & 0,05 & $\mathbf{0 , 0 1}$ \\
\hline Perlakuan & 15 & 153.79 & 10.25 & $51.55^{* *}$ & 2.40 & 3.52 \\
\hline Kelompok & 1 & 0.64 & 0.64 & $3.30^{\operatorname{tn}}$ & 4.49 & 8.53 \\
\hline (A) & 1 & 0.80 & 0.80 & $4.033^{\text {tn }}$ & 4.49 & 8.53 \\
\hline (B) & 7 & 151.18 & 21.60 & $108.59^{* *}$ & 2.66 & 4.03 \\
\hline$(\mathbf{A} \times \mathbf{B})$ & 7 & 1.81 & 0.26 & $1.30^{\mathrm{tn}}$ & 2.66 & 4.03 \\
\hline Galat & 16 & 3 & 0.20 & & & \\
\hline Total & 32 & & & & & \\
\hline \multicolumn{7}{|l|}{ Keterangan: } \\
\hline$(\mathrm{SK})$ & \multicolumn{6}{|c|}{ Sumber Keragaman } \\
\hline (DB) & \multicolumn{6}{|c|}{ Derajat Bebas } \\
\hline$(\mathrm{JK})$ & \multicolumn{6}{|c|}{ Jumlah Kuadrat } \\
\hline$(\mathrm{KT})$ & \multicolumn{6}{|c|}{ Kuadrat Tengah } \\
\hline (A) & \multicolumn{6}{|c|}{ Jenis Ikan cakalang dan Ikan Tongkol } \\
\hline (B) & \multicolumn{6}{|c|}{ Lama Penyimpanan } \\
\hline$(\mathrm{A} \times \mathrm{B})$ & \multirow{2}{*}{\multicolumn{6}{|c|}{ Jenis Ikan dan Lama penyimpanan }} \\
\hline ** & \multicolumn{2}{|c|}{ Berbeda Sangat Nyata } & & & & \\
\hline tn & \multicolumn{6}{|c|}{ Berbeda Tidak Nyata } \\
\hline
\end{tabular}

Hasil analisis sidik ragam diatas menunjukan bahwa untuk perlakuan jenis ikan memberikan pengaruh yang tidak nyata $(\mathrm{P}<$ 0,01 dan 0,05) dan untuk perlakuan lama penyimpanan memberikan pengaruh yang berbeda sangat nyata $(\mathrm{P}>0,010,05)$. Dari hasil tersebut maka dilakukan uji lanjut BNT. Berdasarkan hasil uji lanjut menujukan bahwa lama penyimpanan memberikan pengaruh yang berbeda sangat nyata.

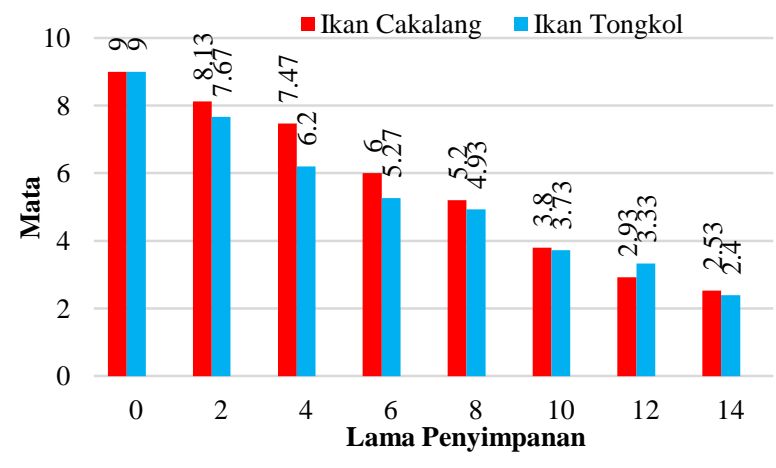

Pada gambar histogram di atas menunjukan bahwa nilai organoleptik mata menurun dari hari $\mathrm{k} 2$ sampai 14. Hal ini diperkuat oleh pernyataan ilyas (1983), bahwa salah satu akibat dari mulai berkembangnya bakteri adalah mata jadi terbenam dan pudar sinarnya. Pada penelitian pianusa, (2016) mendapatkan nilai 7,2 dengan lama penyimpanan 6 hari dengan kreteria (Agak cerah, bola mata rata, pupil agak keabu-abuan, kornea agak keruh). Pada BSN, (2006) mengatakan batas ambang iji organoleptic mata yaitu 7. Menurut Berhimpon dkk (2002) pada uji organoleptik ada 3 jenis kelas mutu yaitu mutu kelas 1 nilai $<8$, kelas 2 nilai $<7$ dan kelas 3 nilai $<5$.

\section{Nilai Mb (Mioglobin)}

Data hasil analisis Mioglobin ikan cakalang dan ikan tongkol selama 0 hari dan 14 hari, dalam penyimpanan dingin dalam cool box pada suhu 0oC-5oC dapat dilihat pada (tabel 7) dengan rumus sebagai berikut:

Nilai-Mb $=\frac{\text { OD pada } 540 \mathrm{~nm}}{\text { OD pada } 503 \mathrm{~nm}}$

\begin{tabular}{cccccc}
\hline $\begin{array}{c}\text { Perlakuan Jenis } \\
\text { Ikan } \\
(\mathbf{A})\end{array}$ & $\begin{array}{c}\text { Perlakuan } \\
\text { Lama }\end{array}$ & \multicolumn{2}{c}{ Mioglobin } & & Total \\
& $\begin{array}{c}\text { Penyimpanan } \\
(\mathbf{B})\end{array}$ & 1 & 2 & & $\begin{array}{c}\text { Rata- } \\
\text { Rata }\end{array}$ \\
\hline $\begin{array}{c}\text { Ikan } \\
\text { Cakalang }\end{array}$ & 0 & 2 & 2,11 & 4,11 & 2,05 \\
$(\mathbf{A 1})$ & 14 & 0,81 & 0,91 & 1,72 & 0,86 \\
\hline $\begin{array}{c}\text { Ikan } \\
\text { Tongkol }\end{array}$ & 0 & 2,01 & 2,05 & 4,06 & 2,03 \\
$(\mathbf{A 2})$ & 14 & 0,99 & 0,95 & 1,95 & 0,97 \\
\hline
\end{tabular}

Berdasarkan data nilai Mioglobin pada ikan cakalang pada penyimpanan 0 hari yaitu 2,05 dan penyimpanan 14 hari 0,86, sedangkan ikan tongkol penyimpanan 0 hari 2,03 dan penyimpanan 14 hari yaitu 0,97. Kandugan myoglobin dalam daging makin berkurang dengan meningkatnya waktu setelah ikan mati, sedangkan metmioglobin makin bertambah. Warna coklat makin jelas terlihat jika 
kandungan metmioglobin dalam daging mencapai 50\% (Suwetja, 1992).

\section{KESIMPULAN DAN SARAN}

\section{Kesimpulan}

Berdasarkan hasil penelitian nilai TVB$\mathrm{N}$, Organoleptik dan Mioglobin pada Ikan Cakalang (Katsuwonus Pelamis-L) dan Ikan Tongkol (Euthynnus affinis) selama penyimpanan $0,2,4,6,8,10,12$ dan 14 hari, dapat ditarik kesimpulan sebagai berikut:

1. Perlakuan jenis ikan tidak mempengaruhi nilai kadar TVB-N dan nilai Organoleptik.

2. Perlakuan lama penyimpanan mempengaruhi nilai TVB-N dan nilai organoleptik.

3. Dari data organoleptic yang menunjang pada kelas mutu I,II dan III didapatkan organoleptic pada 5 parameter dengan standar kelas mutu III yaitu tidak dibawah nilai 5 ada pada hari ke 8. Sehingga pada organoleptic dapat disimpulkan bahwa ikan masih layak konsumsi yaitu dengan lama penyimpanan 8 hari.

4. Dari data TVB-N yang mengacu pada standar batas ambang kadar TVB-N yaitu $30 \mathrm{mg} \mathrm{N} / 100 \mathrm{~g}$ daging. Dapat di simpulkan daging ikan yang layak konsumsi yaitu ikan cakalang pada penyimpanan 10 hari dan ikan tongkol pada penyimpanan 8 hari.

\section{Saran}

1. Perlu dilakukan penelitian pada suhu penyimpanan yang berbeda untuk dapat melihat cepat lambatnya penurunan mutu.

2. Perlu dilakukan penelitian pada jenis ikan famili scombridae lain untuk mendapatkan ambang batas nilai myoglobin.

\section{DAFTAR PUSTAKA}

Badan Standarisasi Nasional, 2006. Petunjuk Penilaian Organoleptik Atau Sensori SNI No. 01-2346.1-2006. Badan Standarisasi Nasional. Jakarta. http://www.slideshare.net/arbydjactpartii/sni-0123462006-petunjuk-pengujian-organoleptik-dan-atausensori (diunduh 9 januari 2017).
Berhimpon, S,. F.G. Ijong dan P. Moniharapon. 2002. Penilaian Indra. Penuntun Pratikum. FPIK. UNSRAT. Manado.

Hadiwiyoto, S. 1993. Teknologi pengolahan Hasil Perikanan. Jilid I. Penerbit Liberty. Jogyakarta. http://repository.unhas.ac.id/bitsream/handle/1234567 89/4323/Naskah\%20setangkap.pdf. (Diunduh 18 Januari 2017).

Ilyas, S. 1983. Teknologi Refrigran Hasil Perikanan. Jilid 1 Teknik Pembekuan ikan. Cv. Paripurna. Jakarta.

Junianto, 2003. Teknik Penanganan Ikan. Penebar Swadaya. Jakarta.

Murniyati, AS dan Sunarman. 2000. Pendinginan, Pembekuan dan Pengawetan Ikan. Yogyakarta.

Nurjanah., Tati Nurhayati dan Rijan Zakaria, 2011. Kemunduran Mutu Ikan Gurami (Osphronemus gouramy) Pasca Kematian dan Penyimpanan Suhu Chilling. Jurnal Sumber Daya Perairan. Volume 5. Nomor $2 . \quad$ Hal 15 http://journal.ubb.ac.id/index.php/aquatic/issue/downl oad/39/59.(Diunduh 15 Desember 2016).

Pianusa. A.F. 2016. Kajian Perubahan Mutu Kesegaran Ikan Tongkol (Euthynnus Afinnis) Yang Direndam Dalam Ekstrak Rumput Laut (Eucheuma spinosum) Dan Ekstrak Buah Bakau (Sonneratia alba). Skripsi. FPIK. UNSRAT. Manado.

Yanuar, P. 2015. Komposisi Kimiawi Ikan. http://www.academia.edu/8798469/Komposisi_Kimia wi_Ikan (18 Januari 2017).

Winarni, T., Swastawati, F., Darmanto, Y. S., dan Dewi, E. N. 2003. Uji Mutu Terpadu pada Beberapa Spesies Ikan dan Produk Perikanan Di Indonesia. Laporan Akhir Hibah Bersaing XI Perguruan Tinggi. Universitas Diponegoro Semarang. http://ejournal.uajy.ac.id/43821/1/JURNAL-mutuikan-tongkol-dikabupaten gunungkidul-dan-slemandaerah-istimewa-yogyakarta.pdf (diunduh 14 Desember 2016).

Suwetja, 1992b. Perubahan Kadar ATP dan Mioglobin Pada Ikan Tuna dan Pengaruhnya Terhadap Kesegaran Selama Penanganan di Perahu dan Pelabuahan Perikanan. Jurnal Reseach and Development UNSRAT. Vol 3. No 8. Manado.

Suwetja, I. K. 1993. Metode Penentuan Mutu Ikan. Jilid 1. Penentuan Kesegaran. Fakultas Perikanan dan Ilmu Kelauatan. Universitas Sam Ratulangi. Manado.

Suwetja, I. K. 2011. Biokimia Hasil Perikanan. Media Prima Aksara. Jakarta.

Suwetja, I. K. 2013. Indeks Mutu Kesegaran Ikan. Bayumedia Publishing. Malang. 